\title{
Treating periodontitis-a systematic review and meta-analysis comparing ultrasonic and manual subgingival scaling at different probing pocket depths
}

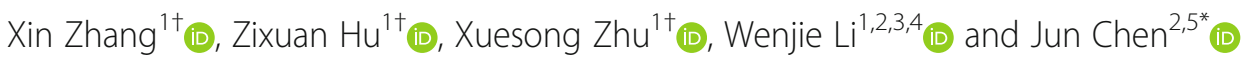

\begin{abstract}
Background: Mechanical plaque removal has been commonly accepted to be the basis for periodontal treatment. This study aims to compare the effectiveness of ultrasonic and manual subgingival scaling at different initial probing pocket depths (PPD) in periodontal treatment.

Methods: English-language databases (PubMed, Cochrane Central Register of Controlled Trials, EMBASE, Medline, and ClinicalTrials.gov, by January, 2019) were searched. Weighted mean differences in primary outcomes, PPD and clinical attachment loss (CAL) reduction, were estimated by random effects model. Secondary outcomes, bleeding on probing (BOP), gingival recession (GR), and post-scaling residual dental calculus, were analyzed by comparing the results of each study. The quality of RCTs was appraised with the Cochrane Collaboration risk of bias tool. The GRADE approach was used to assess quality of evidence.
\end{abstract}

(Continued on next page)

\footnotetext{
* Correspondence: chenjun1222@csu.edu.cn

${ }^{+}$Xin Zhang, Zixuan Hu and Xuesong Zhu contributed equally to this work.

${ }^{2}$ Hunan Key Laboratory of Oral Health Research, Hunan 3D Printing

Engineering Research Center of Oral Care, Hunan Clinical Research Center of

Oral Major Diseases and Oral Health, Central South University, Changsha

410008, People's Republic of China

${ }^{5}$ Department of Periodontics, Xiangya Stomatological Hospital, Xiangya

School of Stomatology, Central South University, Changsha 410008, People's

Republic of China
}

Full list of author information is available at the end of the article

(C) The Author(s). 2020 Open Access This article is licensed under a Creative Commons Attribution 4.0 International License, which permits use, sharing, adaptation, distribution and reproduction in any medium or format, as long as you give appropriate credit to the original author(s) and the source, provide a link to the Creative Commons licence, and indicate if changes were made. The images or other third party material in this article are included in the article's Creative Commons licence, unless indicated otherwise in a credit line to the material. If material is not included in the article's Creative Commons licence and your intended use is not permitted by statutory regulation or exceeds the permitted use, you will need to obtain permission directly from the copyright holder. To view a copy of this licence, visit http://creativecommons.org/licenses/by/4.0/. The Creative Commons Public Domain Dedication waiver (http://creativecommons.org/publicdomain/zero/1.0/) applies to the data made available in this article, unless otherwise stated in a credit line to the data. 
(Continued from previous page)

Results: Ten randomized controlled trials were included out of 1434 identified. Initial PPD and follow-up periods formed subgroups. For 3-months follow-up: (1) too few shallow initial pocket studies available to draw a conclusion; (2) the heterogeneity of medium depth studies was so high that could not be merged to draw a conclusion; (3) deep pocket studies showed no statistical differences in PPD and CAL reduction between ultrasonic and manual groups. For 6-months follow-up: (1) too few shallow initial PPD studies to draw a conclusion; (2) at medium pocket depth, PPD reduction showed manual subgingival scaling better than ultrasound. No statistical differences were observed in CAL reduction between the two approaches; (3) for deep initial PPD studies, both PPD and CAL reduction showed manual subgingival scaling better. GR results indicated no statistical differences at medium and deep initial pocket studies between the two methods. BOP results showed more reduction at deep pocket depths with manual subgingival scaling. No conclusion could be drawn about residual dental calculus.

Conclusion: When initial PPD was 4-6 mm, PPD reduction proved manual subgingival scaling was superior, but CAL results showed no statistical differences between the two means. When initial PPD was $\geq 6 \mathrm{~mm}, \mathrm{PPD}$ and CAL reductions suggested that manual subgingival scaling was superior.

Keywords: Subgingival scaling, Ultrasonic therapy, Periodontal pocket, Periodontal debridement, Meta-analysis

\section{Background}

Periodontitis is characterized by gingivitis and periodontal tissue destruction resulting in alveolar bone and tooth loss [1]. Periodontitis is the sixth most common disease with a standardized prevalence of $11.2 \%$. It is the primary cause of tooth loss and negatively affects oral health, nutrition, self-confidence, and overall health. It associates with various systemic chronic diseases such as angiocardiopathy and diabetes [2,3]. The global burden of periodontal disease remains high, which increased by $57.3 \%$ from 1990 to 2010 [4].

Dental plaque biofilm is the initial factor of periodontitis, which aggregates to trigger immune responses. This tends to destroy surrounded soft tissues and alveolar bone [3]. The goal of periodontal treatment is to control infection, and remove dental plaque, dental calculus, and endotoxins [5]. It is confirmed that subgingival scaling is an effective non-surgical periodontal therapy. In the early stage, subgingival scaling was practiced with manual scaling. In recent years, ultrasonic subgingival scaling has been applied in periodontal clinic [1, 6-9]. Each technique has advantages and disadvantages. Currently there is no universal protocol or clinical guideline for selecting one technique over another.

Many in-vivo studies did not group by initial probing pocket depth (PPD) when comparing ultrasonic and manual subgingival scaling, but different PPD may greatly influence instrument selection. For example, Beuchat found that when initial $\mathrm{PPD}<6 \mathrm{~mm}$, for gingival recession (GR), there was no statistical difference between ultrasonic and manual subgingival scaling $(P<0.05)$. When initial PPD $>7 \mathrm{~mm}$, attachment level (AL) improved more while GR reduced more in using ultrasonic instruments than using manual instruments [10]. It is controversial in terms of when to use manual subgingival instruments and when to use ultrasonic ones.
In this study, we aimed to compare the work effectiveness between ultrasonic and manual subgingival scaling in different initial PPDs. It can provide new evidence for clinical instrument selection and future study.

\section{Methods}

A protocol has been registered at the International Prospective Register of Systematic Reviews (Number CRD42019125067). The content of this article is consistent with the protocol.

\section{Research question}

The focused question was developed in accordance with recognized Patient, Intervention, Comparison, and Outcome (PICO) format: "What's the difference of the work effectiveness between ultrasonic and manual subgingival scaling in periodontal treatment at different initial PPDs?"

\section{Selection criteria \\ Study type}

In-vivo randomized controlled trials (RCT) that compared manual- and ultrasonic- subgingival scaling in periodontal treatment were included. Studies had to be in English. We classify the initial PPDs into: (1) shallow pocket: PPD $\leq 4 \mathrm{~mm}$; (2) medium pocket: $4 \mathrm{~mm}<\mathrm{PPD}<$ $6 \mathrm{~mm}$; or, (3) deep pocket: PPD $\geq 6 \mathrm{~mm}$. A group of studies in each article could not be simultaneously included in different PPD categories. Teeth with single-roots or multi-roots were all included in the study.

\section{Participants}

Adults (age $\geq 18$ ) diagnosed with periodontitis unaccompanied by any other oral or systemic disease and not taking antibiotics. 
Table 1 Included studies characteristics (Primary outcome measures)

\begin{tabular}{|c|c|c|c|c|c|c|c|}
\hline Study & $\begin{array}{l}\text { First Author, } \\
\text { Year } \\
\text { Outcomes } \\
\text { Mean age ( } \pm \\
\text { SEM) Female/ } \\
\text { Male Country }\end{array}$ & PPD & Interventions & Follow Up & Inclusion criteria & Exclusion criteria & $\begin{array}{l}\text { Smoker/ } \\
\text { Non- } \\
\text { smokers } \\
\text { ratio }\end{array}$ \\
\hline \multirow{5}{*}{$\begin{array}{l}\text { Pilot study on the } \\
\text { clinical and } \\
\text { microbiological effect } \\
\text { of subgingival glycine } \\
\text { powder air polishing } \\
\text { using a cannula-like jet } \\
\text { [15] }\end{array}$} & $\begin{array}{c}\text { - Kargas, } \\
\text { K.2015 }\end{array}$ & \multirow[t]{5}{*}{$\begin{array}{l}\text { moderate } \\
\text { pockets }\end{array}$} & \multirow{5}{*}{$\begin{array}{l}\text { ultrasonic } \\
\text { instrumentation } \\
\text { (Piezonâ, Instrument A, } \\
\text { EMS, Nyon, } \\
\text { Switzerland), hand } \\
\text { instruments (Gracey } \\
\text { curettes 3/4, 11/12, 13/ } \\
14, \text { Hu-Friedy, Chicago, } \\
\text { IL, USA) }\end{array}$} & \multirow[t]{5}{*}{6 Months } & \multirow{5}{*}{$\begin{array}{l}\text { (a) Must have been } \\
\text { previously diagnosed } \\
\text { with generalized } \\
\text { chronic periodontitis } \\
\text { (according to } \\
\text { American Academy of } \\
\text { Periodontology) and } \\
\text { successfully treated; (b) } \\
\text { Subsequently, entered } \\
\text { the supportive } \\
\text { treatment phase (SPT), } \\
\text { with at least two non- } \\
\text { bleeding residual } \\
\text { pockets > } 4 \text { mm in } \\
\text { each quadrant; (c) } \\
\text { Have at least } 20 \text { nat- } \\
\text { ural teeth; (d) Non- } \\
\text { smoker; (e) Could not } \\
\text { taken an antibiotic, } \\
\text { anti-inflammatory } \\
\text { medication, corticoste- } \\
\text { roids or other im- } \\
\text { munosuppressive } \\
\text { drugs during the previ- } \\
\text { ous } 6 \text { months; (f) Preg- } \\
\text { nant or lactating } \\
\text { women were also ex- } \\
\text { cluded from this study. }\end{array}$} & \multirow[t]{5}{*}{ None } & \multirow[t]{5}{*}{$\begin{array}{l}\text { No } \\
\text { smoker }\end{array}$} \\
\hline & - PPD, CAL & & & & & & \\
\hline & $-52.50 \pm 9.54$ & & & & & & \\
\hline & $-12 / 15$ & & & & & & \\
\hline & - Greece & & & & & & \\
\hline \multirow{5}{*}{$\begin{array}{l}\text { Er:YAG lasers versus } \\
\text { ultrasonic and hand } \\
\text { instruments in } \\
\text { periodontal therapy: } \\
\text { clinical parameters, } \\
\text { intracrevicular micro- } \\
\text { organism and } \\
\text { leukocyte counts [13] }\end{array}$} & $\begin{array}{r}\text { - Malali, } \\
\text { E.2012 }\end{array}$ & \multirow[t]{5}{*}{$\begin{array}{l}4-6 \mathrm{~mm} \\
>7 \mathrm{~mm}\end{array}$} & \multirow{5}{*}{$\begin{array}{l}\text { a magnetostrictive } \\
\text { ultrasonic scaler } \\
\text { (Cavitron Bobcat Pro, } \\
\text { Dentsply International } \\
\text { Inc., USA), manual } \\
\text { periodontal curettes } \\
\text { (Gracey, SG \# 5/6, 7/8, } \\
11 / 12,13 / 14, \text { Mini Five } \\
\text { Gracey SAS \# 5/6, 11/ } \\
12, \text { Hu-Friedy Ins. Co., } \\
\text { USA) }\end{array}$} & \multirow[t]{5}{*}{3 Months } & \multirow{5}{*}{$\begin{array}{l}\text { Patients with } \\
\text { generalized } \\
\text { periodontal } \\
\text { breakdown and who } \\
\text { had at least four } \\
\text { single-rooted teeth, } \\
\text { two moderately deep } \\
\text { (probing depth [PD] of } \\
4-6 \text { mm) and two } \\
\text { deep pockets (PD } \geq 7 \\
\text { mm) that had no end- } \\
\text { odontic lesion and no } \\
\text { crown, with mobility } \\
0-2 \text {, and with bleeding } \\
\text { on probing (BOP) were } \\
\text { selected. }\end{array}$} & \multirow{5}{*}{$\begin{array}{l}\text { (a) Periodontal } \\
\text { treatment within the } \\
\text { last } 6 \text { months; (b) Any } \\
\text { systemic disease that } \\
\text { would influence the } \\
\text { periodontal tissues; (c) } \\
\text { Antibiotic used within } \\
\text { last } 6 \text { months; (d) } \\
\text { Pregnancy and } \\
\text { smoking. }\end{array}$} & \multirow[t]{5}{*}{$\begin{array}{l}\text { No } \\
\text { smoker }\end{array}$} \\
\hline & - PPD、CAL & & & & & & \\
\hline & $-48.83 \pm 7.23$ & & & & & & \\
\hline & $-11 / 19$ & & & & & & \\
\hline & - Turkey & & & & & & \\
\hline \multirow{5}{*}{$\begin{array}{l}\text { Hand instrumentation } \\
\text { versus ultrasonic } \\
\text { debridement in the } \\
\text { treatment of chronic } \\
\text { periodontitis: a } \\
\text { randomized clinical } \\
\text { and microbiological } \\
\text { trial [12] }\end{array}$} & $\begin{array}{l}- \text { loannou, } \\
\text { I.2009 }\end{array}$ & \multirow{5}{*}{$\begin{array}{l}<4 \mathrm{~mm} \\
4-6 \mathrm{~mm} \\
>6 \mathrm{~mm}\end{array}$} & \multirow{5}{*}{$\begin{array}{l}\text { UD: (EMS Piezon }{ }^{\oplus}, \\
\text { EMS, Nyon, } \\
\text { Switzerland) with A } \\
\text { and P instruments } \\
\text { (Swiss InstrumentsPM, } \\
\text { EMS) under water } \\
\text { irrigation, SRP:Hu- } \\
\text { Friedy Gracey Standard } \\
\text { Curettes SG 3/4, 11/12, } \\
\text { 13/14, After Five } \\
\text { Curettes SAS 3/4, 11/ } \\
\text { 12, 13/14, Hu-Friedy. }\end{array}$} & \multirow[t]{5}{*}{$\begin{array}{l}3 \text { Months, } \\
6 \text { Months }\end{array}$} & \multirow{5}{*}{$\begin{array}{l}\text { (a) Existence of a } \\
\text { minimum of four sites } \\
\text { with PPD } 5 \mathrm{~mm} \text { in at } \\
\text { least two quadrants of } \\
\text { each of the patients, } \\
\text { demonstrating } \\
\text { bleeding on probing; } \\
\text { (b) No periodontal } \\
\text { treatment during the } \\
\text { previous } 6 \text { months. }\end{array}$} & \multirow{5}{*}{$\begin{array}{l}\text { (a) Compromised } \\
\text { medical condition; (b) } \\
\text { Systemic antibiotics } \\
\text { during treatment or } \\
\text { for the last } 3 \text { months; } \\
\text { (c) Ongoing drug } \\
\text { therapy that might } \\
\text { affect periodontal } \\
\text { therapy; (d) } \\
\text { Requirement for } \\
\text { prophylactic antibiotic } \\
\text { cover of the patient; } \\
\text { (e) Use of } \\
\text { chlorhexidine } \\
\text { mouthwash or any } \\
\text { other antimicrobial } \\
\text { agent; (f) Pregnancy } \\
\text { for female patients. }\end{array}$} & \multirow{5}{*}{$\begin{array}{l}\text { SRP: } 50 \% \\
\text { of } \\
\text { patients } \\
\text { is } \\
\text { smoker; } \\
\text { UD: } \\
52.9 \% \text { of } \\
\text { patients } \\
\text { is } \\
\text { smoker. }\end{array}$} \\
\hline & - PPD, CAL & & & & & & \\
\hline & $\begin{array}{l}\text { - SRP:49.62 } \pm \\
\text { 2.07, UD: } \\
\text { 50.47 } \pm 2.58\end{array}$ & & & & & & \\
\hline & $\begin{array}{l}\text { - SRP:50/50 } \\
\text { UD:70.6/29.4 }\end{array}$ & & & & & & \\
\hline & - Greece & & & & & & \\
\hline
\end{tabular}


Table 1 Included studies characteristics (Primary outcome measures) (Continued)

\begin{tabular}{|c|c|c|c|}
\hline Study & $\begin{array}{l}\text { First Author, } \\
\text { Year } \\
\text { Outcomes } \\
\text { Mean age }( \pm \\
\text { SEM) Female/ } \\
\text { Male Country }\end{array}$ & PPD & Interventions \\
\hline $\begin{array}{l}\text { Non-surgical } \\
\text { periodontal treatment } \\
\text { with a new ultrasonic } \\
\text { device (Vector }{ }^{\text {TM_- }} \\
\text { ultrasonic system) or } \\
\text { hand instruments a } \\
\text { prospective, controlled } \\
\text { clinical study [18] }\end{array}$ & $\begin{array}{l}\text { - Sculean, A. } \\
2004 \\
\text { - PPD、CAL } \\
\text { - } 54 \\
\text { - 24/14(VUS: } \\
\text { 10/9; SRP: } \\
\text { 11/8) } \\
\text {-Germany }\end{array}$ & $\begin{array}{l}4-6 \mathrm{~mm} \\
>6 \mathrm{~mm}\end{array}$ & $\begin{array}{l}\text { VUS: Vector probe, } \\
\text { (Durr Dental, } \\
\text { Bietigheim-Bissingen, } \\
\text { Germany) using } \\
\text { straight and curved } \\
\text { metal curettes and a } \\
\text { polishing fluid (HA par- } \\
\text { ticles < 10um) accord- } \\
\text { ing to the instructions } \\
\text { given by the manufac- } \\
\text { turer, SRP:Hand instru- } \\
\text { ments (Gracey } \\
\text { Curettes, Hu-Friedy } \\
\text { Co., Chicago, IL, USA). }\end{array}$ \\
\hline $\begin{array}{l}\text { Periodontal healing } \\
\text { after non-surgical ther- } \\
\text { apy with a modified } \\
\text { sonic scaler: A con- } \\
\text { trolled clinical trial [17] }\end{array}$ & $\begin{array}{l}\text { - Christgau, } \\
\text { M. } 2006 \\
\text { - PPD, CAL } \\
\text { - } 45.6 \pm 8.0 \\
\text { - } 14 / 6 \\
\text { - Germany }\end{array}$ & $\begin{array}{l}<4 \mathrm{~mm} \\
4-6 \mathrm{~mm} \\
>6 \mathrm{~mm}\end{array}$ & $\begin{array}{l}\text { UD:the modified sonic } \\
\text { scaler system } \\
\text { SonicFlex } 2003 \text { L } \\
\text { (KaVo), SRP:Gracey- } \\
\text { curettes \#1/2, \#7/8, } \\
\# 11 / 12 \text {, \#13/14, } \\
\text { HuFriedy, Chicago, IL, } \\
\text { USA. }\end{array}$ \\
\hline
\end{tabular}

$\begin{array}{lcc}\begin{array}{ll}\text { Full-mouth ultrasonic } \\ \text { debridement versus }\end{array} & \text { - Wennström, } & 5-6 \mathrm{~mm} \text {, } \\ \text { quadrant scaling and } 2005 & 7 \mathrm{~mm} \\ \text { root planing as an } & \text { - PPD、CAL } \\ \text { initial approach in the } & -25-75 \text { years } \\ \text { treatment of chronic } & \text { old, mean } \\ \text { periodontitis* }[14] & \text { age } 49.8 \\ & -19 / \\ & 22(\text { SRP11/10; } \\ & \text { UD8/12) } \\ & - \text { Italy, } \\ & \text { Sweden }\end{array}$

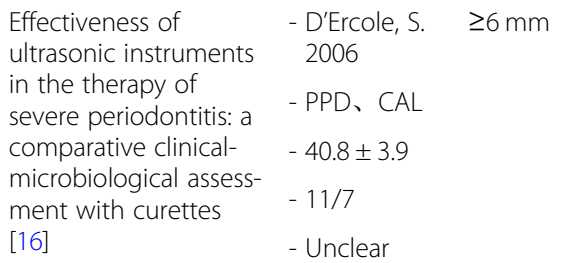
tips, water coolant and Switzerland, SRP:LMdental, Turku, Finland.

UD:a power-driven mechanism Vector $^{\circledR}$ System), SRP: the type of manual instuments is unclear
Follow Up Inclusion criteria

$\begin{array}{ll}\text { Exclusion criteria } & \text { Smoker/ } \\ & \text { Non- } \\ & \text { smokers }\end{array}$

ratio

$\begin{array}{ll}6 \text { Months } & \text { (a) No treatment of } \\ & \text { periodontitis for the } \\ & \text { last 2 years; (b) No use } \\ & \text { of antibiotics for the } \\ & 12 \text { months prior to } \\ & \text { treatment; (c) No } \\ & \text { systemic diseases, and } \\ & \text { (d) Good level of oral } \\ & \text { hygiene. As criterion } \\ & \text { for a good level of oral } \\ & \text { hygiene a mean } \\ & \text { plaque index (PI) } \\ & \text { score }<1 \text { was chosen. } \\ & \\ \text { All had generalized } & \text { moderate to } \\ \text { 1 Month } & \text { progressive chronic } \\ \text { periodontitis, but were } \\ \text { systemically healthy } \\ \text { and had not received } \\ \text { systemic antibiotics for } \\ \text { at least } 3 \text { months } \\ \text { before. Each patient } \\ \text { had to show at least } \\ \text { four teeth per } \\ \text { quadrant with a PpD } \\ \text { of at least } 4 \text { mm. }\end{array}$

UD:EMS Piezon Master 3 Months, (a) A minimum of 18 400 with $A+$ PerioSlim 6 Months teeth; (b) At least eight

(a) Subgingival

Italy: UD teeth; (b) At least eight instrumentation within 4/11, teeth must show 12 months prior to the SRP 4/ probing pocket depths baseline examination; 10, (PPD) of $5 \mathrm{~mm}$ and (b) The use of Sweden: EMS, Nyon, (PPD) of $5 \mathrm{~mm}$ and coverage; (d) Ongoing
No-

UD $7 / 10$

SRP 6/11 smoker bleeding on probing (BOP). At least two of these teeth must have a PPD of $7 \mathrm{~mm}$ and at additional two teeth, the pockets must measure $6 \mathrm{~mm}$ (c) Unremarkable general health according to medical history and clinical judgement; (d) Female patients must not be pregnant.

antibiotics within 3 months prior to the start of the study; (c) Compromised medical conditions requiring prophylactic antibiotic drug therapy that might affect the clinical signs and symptoms of periodontitis.

None

3 Months, (a) Positive for 6 Months, diagnosis of mild-to1 Month severe chronic peri(excluded) odontitis; (b) Good general health according to their medical history; (c) Negative for the use of any antibiotic or antiinflammatory drugs within the 3 months preceding the beginning of the study; (d) Negative for periodontal therapy within 1 year preceding the beginning of 
Table 1 Included studies characteristics (Primary outcome measures) (Continued)

\begin{tabular}{|c|c|c|c|c|c|c|}
\hline Study & $\begin{array}{l}\text { First Author, } \\
\text { Year } \\
\text { Outcomes } \\
\text { Mean age }( \pm \\
\text { SEM) Female/ } \\
\text { Male Country }\end{array}$ & Interventions & Follow Up & Inclusion criteria & Exclusion criteria & $\begin{array}{l}\text { Smoker/ } \\
\text { Non- } \\
\text { smokers } \\
\text { ratio }\end{array}$ \\
\hline & & & & $\begin{array}{l}\text { the study; (e) Experi- } \\
\text { mental sites (test and } \\
\text { control) localized in } \\
\text { the interproximal pos- } \\
\text { ition of two different } \\
\text { teeth in the same sub- } \\
\text { ject (split-mouth de- } \\
\text { sign); (f) Probing depth } \\
\text { (PD) values equal to or } \\
\text { more than } 6 \text { mm in } \\
\text { the experimental sites; } \\
\text { (g) Difference of PD in } \\
\text { the experimental sites } \\
\text { (test and control) not } \\
\text { exceeding } 2 \text { mm; (h) } \\
\text { Presence of at least } \\
\text { ten teeth for each den- } \\
\text { tal arch. Pregnant or } \\
\text { nursing females were } \\
\text { excluded from the } \\
\text { study. }\end{array}$ & & \\
\hline
\end{tabular}

$S R P$, scaling and root planing with hand instrument, UD ultrasonic debridement, $P P D$ probing pocket depth, CAL clinical attachment level

*: The data is from two study centers: Italy and Sweden

\section{Intervention}

Meta-analysis sought to eliminate bias caused by different initial PPDs to compare ultrasonic subgingival scaling with manual ones. No distinctions were made between ultrasonic subgingival instrument makers or models. A Gracey scraper was chosen as the manual instrument.

\section{Outcomes}

A study may have primary and secondary indicators. Each indicator was processed differently. Not all outcomes were consistent with the criteria. The outcomes included appear in tables (Table 1 and 2).

\section{(1) Primary outcomes:}

PPD and clinical attachment loss (CAL) were the primary outcomes to compare different subgroup outcomes.

(2) Secondary outcomes:

Bleeding on probing (BOP), gingival recession (GR), and post-scaling residual dental calculus were used as measures. These indicators are of interest, but data about them could not be extracted for meta-analysis due to the limited number of studies, their different measurements, and definitions. They were analyzed by comparing the results of each study.
Studies meeting the following conditions were excluded: (1) follow-up in less than 3 months; (2) treatment during follow-up. Cluster trials were not included.

\section{Search strategy}

PubMed, Cochrane Central Register of Controlled Trials, EMBASE, Medline were searched until January, 2019 for relevant studies. The search was performed using a combination of controlled vocabulary and key words (Appendix 1). Only English articles were searched. No time restrictions were imposed.

For potentially eligible studies, we searched ClinicalTrials.gov for prospective trial registers for controlled trials, with publication time up to January, 2019. In addition, the reference lists from the selected articles were checked for further studies qualifying for the review. Only articles written in English were selected. In this process, an eligible study contrasted ultrasonic and manual subgingival scaling, whether or not other methods were compared at the same time. And the initial PPD of each subject in an eligible study could be classified into shallow, medium or deep pocket at the same time.

\section{Data collection and analyses} Study selection and quality assessment

Three review authors (XZ, ZH, and XSZ) independently searched and included eligible studies, using the same 
Table 2 Included studies characteristics (Secondary outcome measures)

\begin{tabular}{|c|c|c|c|c|c|c|c|}
\hline Study & $\begin{array}{l}\text { First Author, } \\
\text { Year } \\
\text { Outcomes } \\
\text { Mean age }( \pm \\
\text { SEM) } \\
\text { Female/Male } \\
\text { Country }\end{array}$ & PPD & Interventions & Follow Up & Inclusion criteria & $\begin{array}{l}\text { Exclusion } \\
\text { criteria }\end{array}$ & $\begin{array}{l}\text { Smoker/ } \\
\text { Non- } \\
\text { smokers } \\
\text { ratio }\end{array}$ \\
\hline \multirow{5}{*}{$\begin{array}{l}\text { Pilot study on the clinical } \\
\text { and microbiological effect } \\
\text { of subgingival glycine } \\
\text { powder air polishing using } \\
\text { a cannula-like jet [15] }\end{array}$} & $\begin{array}{l}\text { - Kargas, K. } \\
2015\end{array}$ & \multirow[t]{5}{*}{$\begin{array}{l}\text { Moderate } \\
\text { pockets }\end{array}$} & \multirow{5}{*}{$\begin{array}{l}\text { Ultrasonic instrumentation } \\
\text { (Piezonâ, Instrument A, } \\
\text { EMS, Nyon, Switzerland), } \\
\text { Hand instruments (Gracey } \\
\text { curettes } 3 / 4,11 / 12,13 / 14 \text {, } \\
\text { Hu-Friedy, Chicago, IL, } \\
\text { USA) }\end{array}$} & \multirow[t]{5}{*}{6 Months } & \multirow{5}{*}{$\begin{array}{l}\text { (a) Must have been } \\
\text { previously diagnosed with } \\
\text { generalized chronic } \\
\text { periodontitis (according to } \\
\text { American Academy of } \\
\text { Periodontology) and } \\
\text { successfully treated; (b) } \\
\text { Subsequently, entered the } \\
\text { supportive treatment } \\
\text { phase (SPT), with at least } \\
\text { two non-bleeding residual } \\
\text { pockets }>4 \text { mm in each } \\
\text { quadrant; (c) Have at least } \\
20 \text { natural teeth; (d) Non- } \\
\text { smoker; (e) Could not } \\
\text { taken an antibiotic, anti- } \\
\text { inflammatory medication, } \\
\text { corticosteroids or other } \\
\text { immunosuppressive drugs } \\
\text { during the previous } 6 \\
\text { months; (f) Pregnant or } \\
\text { lactating women were also } \\
\text { excluded from this study. }\end{array}$} & \multirow{5}{*}{ None } & \multirow[t]{5}{*}{$\begin{array}{l}\text { No } \\
\text { smoker }\end{array}$} \\
\hline & - GR & & & & & & \\
\hline & $-52.50 \pm 9.54$ & & & & & & \\
\hline & $-12 / 15$ & & & & & & \\
\hline & - Greece & & & & & & \\
\hline \multirow{5}{*}{$\begin{array}{l}\text { Clinical evaluation of the } \\
\text { speed and effectiveness of } \\
\text { subgingival calculus } \\
\text { removal on single-rooted } \\
\text { teeth with diamond- } \\
\text { coated ultrasonic tips [20] }\end{array}$} & $\begin{array}{l}\text { - Yukna, R. A. } \\
1997\end{array}$ & \multirow[t]{5}{*}{$\begin{array}{l}5-6 \mathrm{~mm} \\
7-8 \mathrm{~mm}\end{array}$} & \multirow[t]{5}{*}{$\begin{array}{l}\text { Hand curets, Plain } \\
\text { ultrasonic }\end{array}$} & \multirow{5}{*}{$\begin{array}{l}\text { Extract } \\
\text { the teeth } \\
\text { after the } \\
\text { treatment }\end{array}$} & \multirow{5}{*}{$\begin{array}{l}\text { Subjects had moderately } \\
\text { deep probing depths ( }>5 \\
\text { mm in depth), had not } \\
\text { received scaling and root } \\
\text { planing for at least } 6 \\
\text { months prior to the study, } \\
\text { and exhibited clinically } \\
\text { and/or radiographically } \\
\text { evident subgingival } \\
\text { calculus on the study } \\
\text { teeth. }\end{array}$} & \multirow[t]{5}{*}{ None } & \multirow[t]{5}{*}{ Unclear } \\
\hline & $\begin{array}{l}\text { - The mean } \\
\text { percent of } \\
\text { calculus } \\
\text { remaining }\end{array}$ & & & & & & \\
\hline & - Unclear & & & & & & \\
\hline & - Unclear & & & & & & \\
\hline & - America & & & & & & \\
\hline \multirow{5}{*}{$\begin{array}{l}\text { The effectiveness of the } \\
\text { Titan-S sonic scaler versus } \\
\text { curettes in the removal of } \\
\text { subgingival calculus. A hu- } \\
\text { man surgical evaluation } \\
\text { [21] }\end{array}$} & $\begin{array}{l}\text { - Gellin, R. G. } \\
1986\end{array}$ & \multirow{5}{*}{$\begin{array}{l}<3 \mathrm{~mm} \\
4-5 \mathrm{~mm} \\
6-12 \mathrm{~mm}\end{array}$} & \multirow{5}{*}{$\begin{array}{l}\text { Ultrasonic instrument } \\
\text { (Titan-S), Hand instrument } \\
\text { (Gracey curette and the } \\
\text { McCall's) }\end{array}$} & \multirow{5}{*}{$\begin{array}{l}\text { Extract } \\
\text { the teeth } \\
\text { after the } \\
\text { treatment }\end{array}$} & \multirow{5}{*}{$\begin{array}{l}\text { Exhibit radiographie } \\
\text { evidence of subgingival } \\
\text { calculus or a clinically } \\
\text { detectable ledge of } \\
\text { subgingival calculus on at } \\
\text { least one interproximal } \\
\text { surface per quadrant, and } \\
\text { have no systemic disease } \\
\text { contraindicating } \\
\text { periodontal therapy or the } \\
\text { use of local anesthetics. }\end{array}$} & \multirow[t]{5}{*}{ None } & \multirow[t]{5}{*}{ Unclear } \\
\hline & $\begin{array}{l}\text { - The } \\
\text { percentage } \\
\text { of surfaces } \\
\text { with } \\
\text { residual } \\
\text { calculus }\end{array}$ & & & & & & \\
\hline & - Unclear & & & & & & \\
\hline & - Unclear & & & & & & \\
\hline & - America & & & & & & \\
\hline \multirow{5}{*}{$\begin{array}{l}\text { Non-surgical periodontal } \\
\text { treatment with a new } \\
\text { ultrasonic device (Vectorim_- } \\
\text { ultrasonic system) or hand } \\
\text { instruments a prospective, } \\
\text { controlled clinical study } \\
\text { [18] }\end{array}$} & $\begin{array}{l}\text { - Sculean, A. } \\
2004\end{array}$ & \multirow[t]{5}{*}{$\begin{array}{l}4-6 \mathrm{~mm} \\
>6 \mathrm{~mm}\end{array}$} & \multirow{5}{*}{$\begin{array}{l}\text { UD: Vector probe, (Durr } \\
\text { Dental, Bietigheim- } \\
\text { Bissingen,Germany) using } \\
\text { straight and curved metal } \\
\text { curettes and a polishing } \\
\text { fluid (HA particles < 10um) } \\
\text { according to the instruc- } \\
\text { tions given by the manu- } \\
\text { facturer, SRP:Hand } \\
\text { instruments (Gracey Cu- } \\
\text { rettes, Hu-Friedy Co., Chi- } \\
\text { cago, IL, USA). }\end{array}$} & \multirow[t]{5}{*}{6 Months } & \multirow{5}{*}{$\begin{array}{l}\text { (a) No treatment of } \\
\text { periodontitis for the last } 2 \\
\text { years; (b) No use of } \\
\text { antibiotics for the } 12 \\
\text { months prior to treatment; } \\
\text { (c) No systemic diseases; } \\
\text { (d) Good level of oral } \\
\text { hygiene. As criterion for a } \\
\text { good level of oral hygiene } \\
\text { a mean plaque index (PI) } \\
\text { score }<1 \text { was chosen. }\end{array}$} & \multirow[t]{5}{*}{ None } & \multirow[t]{5}{*}{ Unclear } \\
\hline & - GR, BOP & & & & & & \\
\hline & -54 & & & & & & \\
\hline & $\begin{array}{l}\text { - 24/14(VUS: } \\
\text { 10/9; SRP: } \\
\text { 11/8) }\end{array}$ & & & & & & \\
\hline & -Germany & & & & & & \\
\hline Periodontal healing after & - Christgau, & $<4 \mathrm{~mm}$ & UD:the modified sonic & 6 Months, & All had generalized & None & $14 / 6$ \\
\hline
\end{tabular}


Table 2 Included studies characteristics (Secondary outcome measures) (Continued)

\begin{tabular}{|c|c|c|c|c|c|c|c|}
\hline Study & $\begin{array}{l}\text { First Author, } \\
\text { Year } \\
\text { Outcomes } \\
\text { Mean age ( } \pm \\
\text { SEM) } \\
\text { Female/Male } \\
\text { Country }\end{array}$ & PPD & Interventions & Follow Up & Inclusion criteria & $\begin{array}{l}\text { Exclusion } \\
\text { criteria }\end{array}$ & $\begin{array}{l}\text { Smoker/ } \\
\text { Non- } \\
\text { smokers } \\
\text { ratio }\end{array}$ \\
\hline \multirow{5}{*}{$\begin{array}{l}\text { non-surgical therapy with } \\
\text { a modified sonic scaler: A } \\
\text { controlled clinical trial [17] }\end{array}$} & M. 2006 & \multirow{5}{*}{$\begin{array}{l}4-6 \mathrm{~mm} \\
>6 \mathrm{~mm}\end{array}$} & \multirow{5}{*}{$\begin{array}{l}\text { scaler system SonicFlex } \\
2003 \text { L (KaVo), SRP:Gracey- } \\
\text { curettes \#1/2, \#7/8, \#11/12, } \\
\# 13 / 14, \text { HuFriedy, Chicago, } \\
\text { IL, USA. }\end{array}$} & \multirow{5}{*}{$\begin{array}{l}1 \text { Month } \\
\text { (excluded) }\end{array}$} & \multirow{5}{*}{$\begin{array}{l}\text { moderate to progressive } \\
\text { chronic periodontitis, but } \\
\text { were systemically healthy } \\
\text { and had not received } \\
\text { systemic antibiotics for at } \\
\text { least } 3 \text { months before. } \\
\text { Each patient had to show } \\
\text { at least four teeth per } \\
\text { quadrant with a PPD of at } \\
\text { least } 4 \mathrm{~mm} \text {. }\end{array}$} & & \\
\hline & - BOP, GR & & & & & & \\
\hline & $-45.6 \pm 8.0$ & & & & & & \\
\hline & $-14 / 6$ & & & & & & \\
\hline & - Germany & & & & & & \\
\hline \multirow{5}{*}{$\begin{array}{l}\text { Influence of fluorescence- } \\
\text { controlled Er:YAG laser ra- } \\
\text { diation, the Vector }{ }^{T M} \text { sys- } \\
\text { tem and hand instruments } \\
\text { on periodontally diseased } \\
\text { root surfaces in vivo [19] }\end{array}$} & $\begin{array}{l}\text { - Schwarz, F. } \\
2006\end{array}$ & \multirow[t]{5}{*}{$>6 \mathrm{~mm}$} & \multirow{5}{*}{$\begin{array}{l}\text { UD:ultrasonic system } \\
\text { (Vectorm, Dürr,Bietigheim- } \\
\text { Bissingen,Germany) and a } \\
\text { polishing fluid } \\
\text { (hydroxylapatite particles } \\
<10 \text { um) was used } \\
\text { according to the } \\
\text { instructions given by the } \\
\text { manufacturer(70\% power } \\
\text { setting). SRP: Gracey curets } \\
\text { (Hu-Friedy Co., Chicago,IL, } \\
\text { USA) }\end{array}$} & \multirow{5}{*}{$\begin{array}{l}\text { Extract } \\
\text { the teeth } \\
\text { after the } \\
\text { treatment }\end{array}$} & \multirow{5}{*}{$\begin{array}{l}\text { (a) Probing pocket depths } \\
\text { (> } 6 \text { mm) on at least two } \\
\text { aspects (mesio-buccal/ } \\
\text { mesio-lingual and disto- } \\
\text { buccal/disto-lingual) as } \\
\text { measured from the gin- } \\
\text { gival margin to the bot- } \\
\text { tom of the pocket; (b) No } \\
\text { signs of carious or artificial } \\
\text { damage on the root sur- } \\
\text { face; (c) No periodontal } \\
\text { root surface treatment } \\
\text { within the last } 12 \text { months; } \\
\text { (d) No root fractures or } \\
\text { anatomical abnormalities. }\end{array}$} & \multirow{5}{*}{$\begin{array}{l}\text { Patients } \\
\text { suffering } \\
\text { from } \\
\text { systemic } \\
\text { diseases } \\
\text { were } \\
\text { excluded } \\
\text { from the } \\
\text { study. }\end{array}$} & \multirow[t]{5}{*}{ Unclear } \\
\hline & $\begin{array}{l}\text { - The } \\
\text { roughness } \\
\text { of } \\
\text { cementum } \\
\text { surface }\end{array}$ & & & & & & \\
\hline & -44.8 & & & & & & \\
\hline & $-7 / 5$ & & & & & & \\
\hline & - Germany & & & & & & \\
\hline
\end{tabular}

$\overline{S R P}$, scaling and root planing, UD ultrasonic debridement; GR gingival recession, $B O P$ bleeding on probing

search strategy which had been completed and improved. The quality of each study was reviewed and evaluated for 3 times by three authors and relevant data were extracted. When there was a disagreement whether to include or not, a discussion with other authors (JC and WL) was held and an agreement reached on inclusion or exclusion.

A study's methodological quality was assessed using the original publication. Trial quality was evaluated using Cochrane review bias assessment risk criteria [11]. The GRADE approach was used to assess quality of evidence.

This included random sequence generation (selection bias), allocation concealment (selection bias), blinding of participants and personnel blinding (performance bias), outcome assessment blinding (detection bias), incomplete outcome data (attrition bias), selective reporting (reporting bias) and other biases. Possible ratings were ranked by risk: low $(\mathrm{L})$; high $(\mathrm{H})$; uncertain $(\mathrm{U})$.

\section{Statistical analyses}

When appropriate, data extracted was combined for meta-analysis using Review Manager 5.3. Effect size was estimated and reported as the mean difference (MD) for continuous variables with a $95 \%$ confidence interval (CI). Weight was calculated in individual studies based on the inverse of variance. This study used a random-effects model for analyses due to expected heterogeneity of the studies selected. Study statistical homogeneity was assessed using a Cochran test and by examining the observed variances in effect sizes and residual variance. $\mathrm{I}^{2}$ was calculated to quantify heterogeneity. $\mathrm{I}^{2}>50 \%$ was considered significant [11]. No statistical corrections were used to adjust for multiple analyses. We set the ultrasonic subgingival scaling as the experimental group and the manual subgingival scaling as the control group.

According to Cochrane reviews [11], in meta-analysis, studies with baseline changes as outcomes could be combined with those with final measurements as outcomes. In randomized trials, differences in mean values obtained from baseline changes were usually analyzed on the basis of final measurements and obtained the same effects. In this meta-analysis, baseline changes and final measurements from different studies were combined.

The reason of disagreement from previous studies about ultrasonic and manual subgingival scaling might be that they did not compare them in the same initial pocket depth. In other words, they did not control the variate of initial PPD. So, in this study, we established three subgroups based upon initial pocket depth: shallow $(\leq 4 \mathrm{~mm})$; medium (4-6 mm); and deep ( $\geq 6 \mathrm{~mm})$, to eliminate the effect of the initial PPD to the result. 


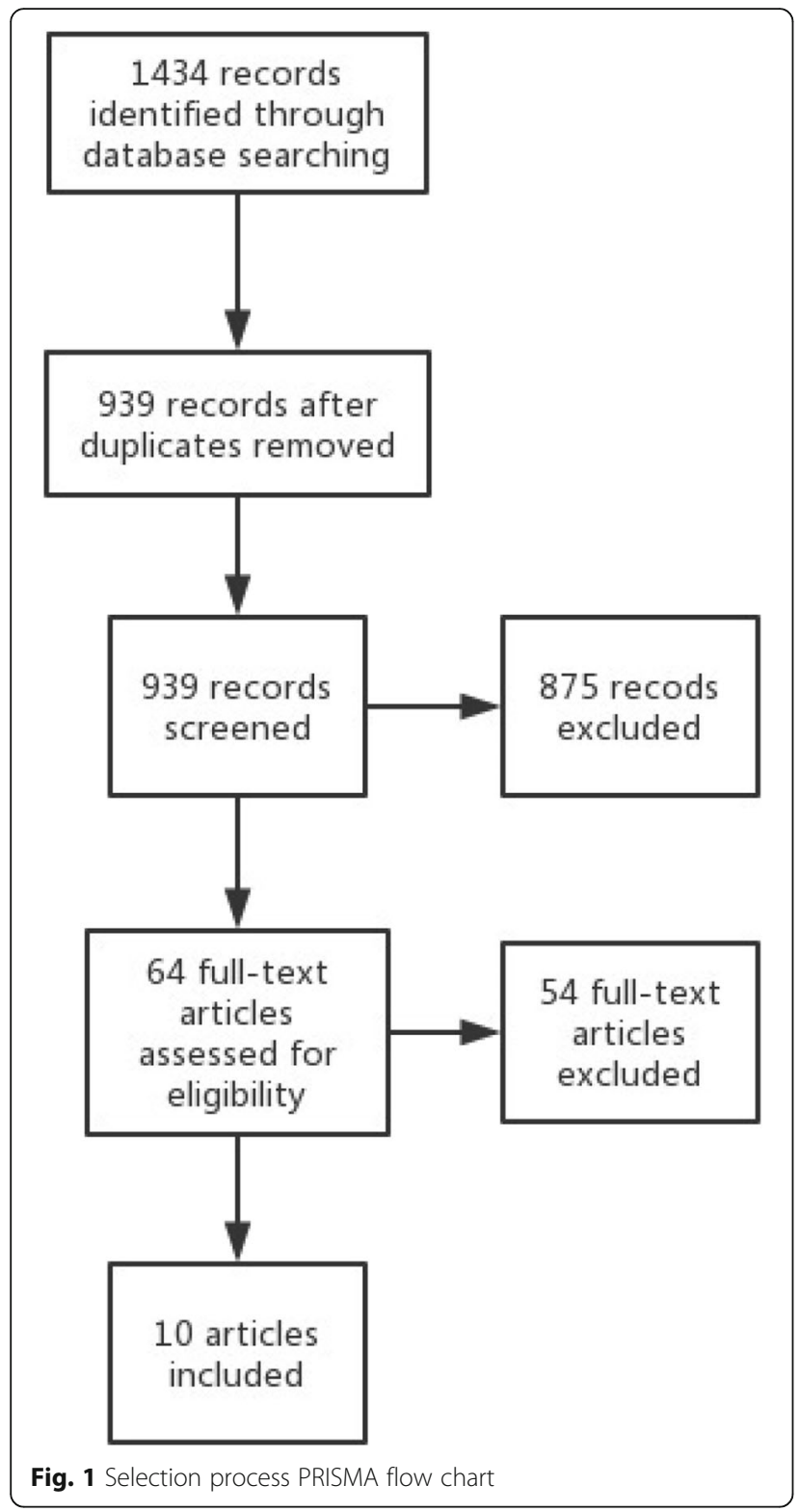

If a study had two initial PPD groups that could be included in one subgroup, data was combined to conform to the depth classification, using the formulas in Appendix 2 [11].

\section{Sensitive analysis}

Pre-planned sensitivity analysis had been done, analyzing the data in the same follow-up time and initial pocket depth: shallow ( $\leq 4 \mathrm{~mm})$, medium (4-6 mm), or deep $(\geq 6$ $\mathrm{mm})$. And we deleted a study each time and performed a new meta-analysis to see if the heterogeneity had changed significantly. If a study was deleted and the heterogeneity was significantly reduced, it was considered to be the main source of heterogeneity, needing further read and evaluation.

\section{Results}

Study selection

There were 1434 studies searched. References in selected papers were searched and no additional studies were located. After reading full texts, ten studies were finally selected. Process selection appears in Fig. 1.

There were 495 duplicates in the 1434 studies. 875 studies were ruled out after reading titles and abstracts. Another 43 studies were ruled out after reading the full text. There were 11 unavailable or awaiting classifications. Finally, 10 studies were included. Studies eventually included were from 2004 to 2015.

\section{Study characteristics}

All research included were RCTs. Follow-up periods were 3 and 6 months. Characteristics of articles selected for primary outcomes appear in Table 1. Characteristics of articles selected for secondary outcomes appear in Table 2. Reasons for study exclusion appear in Table $3[5,6$, 10, 24-63].

Limited information of 11 studies could be obtained from the publication. Inclusion, or exclusion could not be decided because of unobtainable full texts and unknown specific conditions. These appear in Appendix 3.

\section{Quality and risk of bias assessment}

Bias analysis results for the studies appear in Appendix 4 and 5 . Most studies did not have high bias risks. Funnel plots could not be done due to limited number of studies $(<10)$.

\section{Meta-analysis results of primary outcomes}

The follow-up period lengths of the studies varied. Most were 3 and 6 months. This allowed for grouping into 3and 6-months and reduced heterogeneity.

Outcome 1:PPD (Fig.2)

(1) 3 months: (Fig. 2a)

a) Initial PPD $\leq 4 \mathrm{~mm}$ Only one met the criteria, which reported no statistical differences between ultrasonic and manual subgingival scaling [12].

b) Initial PPD > $4 \mathrm{~mm}$ When initial PPD was medium, differences between ultrasonic and manual subgingival scaling were statistically significant. PPD reduction after manual 
Table 3 Reasons for excluding studies

\begin{tabular}{ll}
\hline Study & Reasons \\
\hline$[24-32]$ & No UD-to-SRP comparisons. \\
{$[35-54]$} & Different PPD categories present in the same study or experimental group. \\
{$[56]$} & UD-SRP comparisons present and different PPD categories in the same study or experimental group. \\
{$[57,58]$} & An in vitro study. \\
{$[10,59]$} & Uncertain sample size. \\
{$[60,61]$} & Study results were diagrams with unclear data. \\
{$[5]$} & There were treatments after the initial treatments during a follow-up period. \\
{$[62]$} & Follow-up was 24 months which is a long enough period for tissue changes affected factors other \\
{$[63]$} & than the interventions. The injured tissue may have completely recovered spontaneously. \\
& At each reassessment, study data was measured using different categories of PPD making it impossible \\
\hline
\end{tabular}

subgingival scaling was greater than ultrasonic instruments (MD 0.14, 95\% CI [0.02, 0.26], $P=$ $0.02)$. Heterogeneity was great $\left(\mathrm{Tau}^{2}=0.01 ; \mathrm{Chi}^{2}=\right.$ 28.94, $\left.\mathrm{df}=3(P<0.00001) ; \mathrm{I}^{2}=90 \%\right)[12-15]$. When initial PPD was deep, heterogeneity was acceptable $\left(\mathrm{Tau}^{2}=0.01 ; \mathrm{Chi}^{2}=4.24, \mathrm{df}=3(P=\right.$ $\left.0.24) ; I^{2}=29 \%\right)$. PPD reduction after the two treatments were not statistically significant (MD $0.13,95 \% \mathrm{CI}[-0.02,0.28], P=0.09)[12-14,16]$.

(2) 6 months: (Fig. 2b)

a) Initial PPD $\leq 4 \mathrm{~mm}$

Two studies [12, 17] met the criteria as they used baseline changes as outcomes and one baseline changes value of 0 . A meta-analysis could not be done using the two studies. They both reported no statistical differences between ultrasonic and manual subgingival scaling.

b) Initial $\mathrm{PPD}>4 \mathrm{~mm}$

When initial PPD was medium, differences between ultrasonic and manual subgingival scaling were not statistically significant (MD 0.19, 95\%CI [0.11, 0.27], $P=$ $0.22)$. Heterogeneity was large $\left(\mathrm{Tau}^{2}=0.02 ; \mathrm{Chi}^{2}=25.89\right.$, $\left.\mathrm{df}=3(P<0.0001) ; \mathrm{I}^{2}=88 \%\right)[12,15,17,18]$.

When initial PPD was deep, heterogeneity was also great $\left(\mathrm{Tau}^{2}=0.08 ; \mathrm{Chi}^{2}=8.74, \mathrm{df}=3(P=0.03) ; \mathrm{I}^{2}=66 \%\right)$. PPD reduction after manual subgingival scaling was greater than ultrasonic instruments with a statistically significant difference (MD 0.50, 95\%CI [0.10, 0.89], $P=0.01$ ) $[12,16-18]$.

\section{Outcome 2:CAL (Fig. 3)}

(1) 3 months: (Fig. 3a)

a) Initial PPD $\leq 4 \mathrm{~mm}$

Only one met the criteria, reporting no statistically significant difference between the two methods [12].

b) Initial PPD $>4 \mathrm{~mm}$

When initial PPD was medium, differences between ultrasonic and manual subgingival scaling were not statistically significant (MD $-0.08,95 \% \mathrm{CI}[-0.18,0.03], P=$ $0.14)$. Heterogeneity was great $\left(\mathrm{Tau}^{2}=0.01 ; \mathrm{Chi}^{2}=10.92\right.$, $\left.\mathrm{df}=3(\mathrm{P}=0.01) ; \mathrm{I}^{2}=73 \%\right)[12-15]$.

When initial PPD was deep, difference between ultrasonic and manual subgingival scaling was not statistically significant (MD -0.06, 95\%CI $[-0.58,0.46], P=0.81$ ). Heterogeneity was also high $\left(\mathrm{Tau}^{2}=0.16 ; \mathrm{Chi}^{2}=23.28\right.$, $\left.\mathrm{df}=3(P<0.0001) ; \mathrm{I}^{2}=87 \%\right)[12-14,16]$.

(2) 6 months: (Fig. 3b)

a) Initial $\mathrm{PPD} \leq 4 \mathrm{~mm}$

The heterogeneity of the two studies was too large $\left(\mathrm{Tau}^{2}=0.10 ; \mathrm{Chi}^{2}=10.55, \mathrm{df}=1 \quad(P=0.001) ; \mathrm{I}^{2}=91 \%\right)$ for a meta-analysis to be performed. They both indicated no statistically significant differences between ultrasonic and manual instruments $[12,17]$.

b) Initial $\mathrm{PPD}>4 \mathrm{~mm}$ 


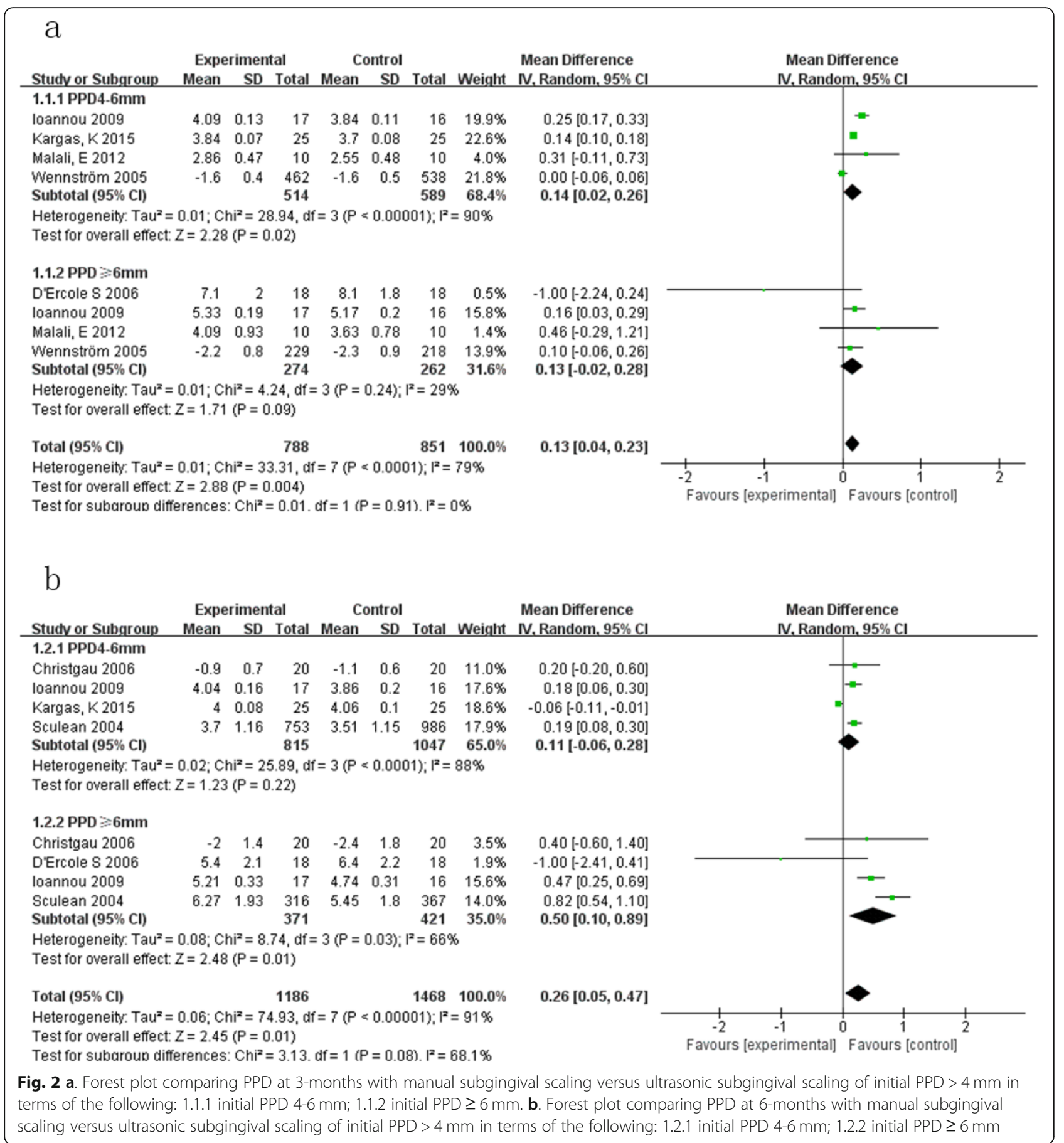

No statistically significant differences were found between the ultrasonic and manual subgingival scaling when initial PPD was medium (MD -0.06, 95\%CI $[-0.17,0.06], P=0.33)$. Heterogeneity was slightly great $\left(\mathrm{Tau}^{2}=0.01 ; \mathrm{Chi}^{2}=6.29, \mathrm{df}=3(P=0.10) ; \mathrm{I}^{2}=52 \%\right)[12$, $15,17,18]$.

At deep pocket depth, differences between the two were not statistically significant (MD 0.28, 95\%CI [-0.20, 0.77],
$P=0.26)$. Heterogeneity was large $\left(\mathrm{Tau}^{2}=0.15 ; \mathrm{Chi}^{2}=\right.$ $\left.10.37, \mathrm{df}=3(P=0.02) ; \mathrm{I}^{2}=71 \%\right)[12,16-18]$.

\section{Secondary outcome measures}

(1) GR: Sculean et al. [18] indicated no statistical differences studying single or multiply-root teeth between ultrasonic and manual subgingival scaling 

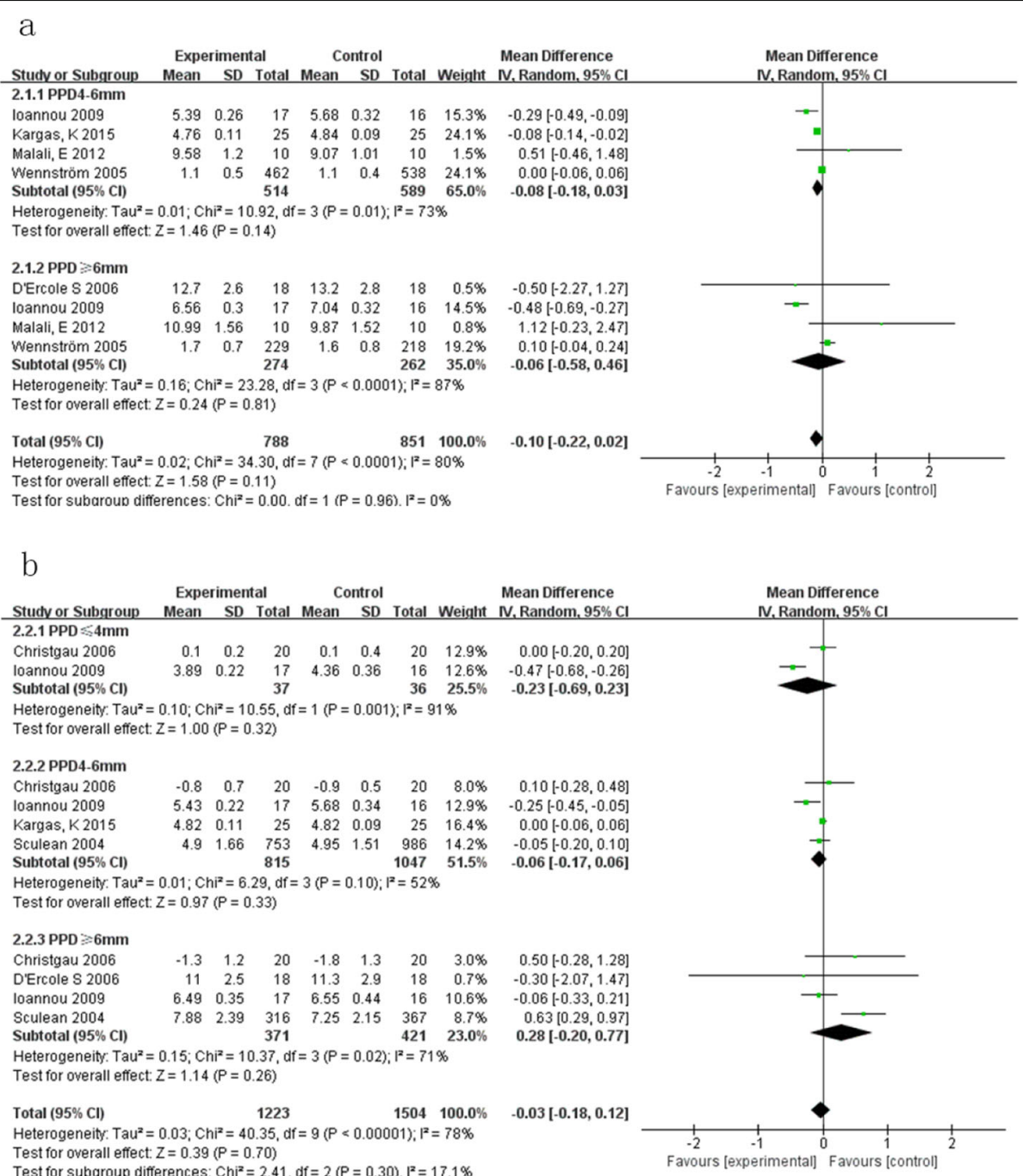

Fig. 3 a. Forest plot comparing CAL at 3-months with manual subgingival scaling versus ultrasonic subgingival scaling of initial PPD $>4 \mathrm{~mm}$ in terms of the following: 2.1.1 initial PPD4-6 mm; 2.1 .2 initial PPD $\geq 6 \mathrm{~mm}$. b. Forest plot comparing CAL at 6-months with manual subgingival scaling I versus ultrasonic subgingival scaling of initial PPD were shallow in terms of the following: 2.2 .1 initial PPD $\leq 4$ mm;2.2.2 initial PPD4-6 mm; 2.2 .3 initial PPD $\geq 6$ mm

at 6-months when initial PPD was deep. Kargas et al. [15] noted that, at medium depths, there were no statistical differences between ultrasonic and manual subgingival scaling at either 3 or 6-months.

(2) BOP: Christgau et al. [17] found that at 6-months, manual subgingival scaling showed greater BOP reduction at initial deep pocket depth compared to ultrasound.

(3) Residual dental calculus: Schwarz et al. [19] indicated that for single-root teeth at deep initial depth, ultrasonic subgingival device was superior to manual instruments in removing subgingival dental calculus. Yukna et al. [20] found no statistical differences in residual dental calculus rates between ultrasonic and manual subgingival scaling with initial PPD at 5-6 $\mathrm{mm}, 7-8 \mathrm{~mm}$ or $>9 \mathrm{~mm}$. Gellin et al. [21] found no statistical differences in dental calculus clearance rates between the two methods when initial PPD was 0-3 mm, 4-5 mm, or, 6-12 mm. When ultrasonic subgingival scaling was combined with manual instruments, the effectiveness was superior to either ultrasonic or manual instruments individually [21].

\section{Discussion \\ Sensitivity analysis \\ Outcome: PPD}

At 3-months, at medium depth, heterogeneity was great $\left(\mathrm{I}^{2}=90 \%\right.$, Fig. 2a). After sensitivity analysis, four studies were found highly heterogeneous to each other and were unsuitable for meta-analysis. After a bias analysis, the heterogeneity source was thought to be: (1) small number of studies; (2) the fact that tissue healing took time and early probing disrupted attachment gains. At 3- 


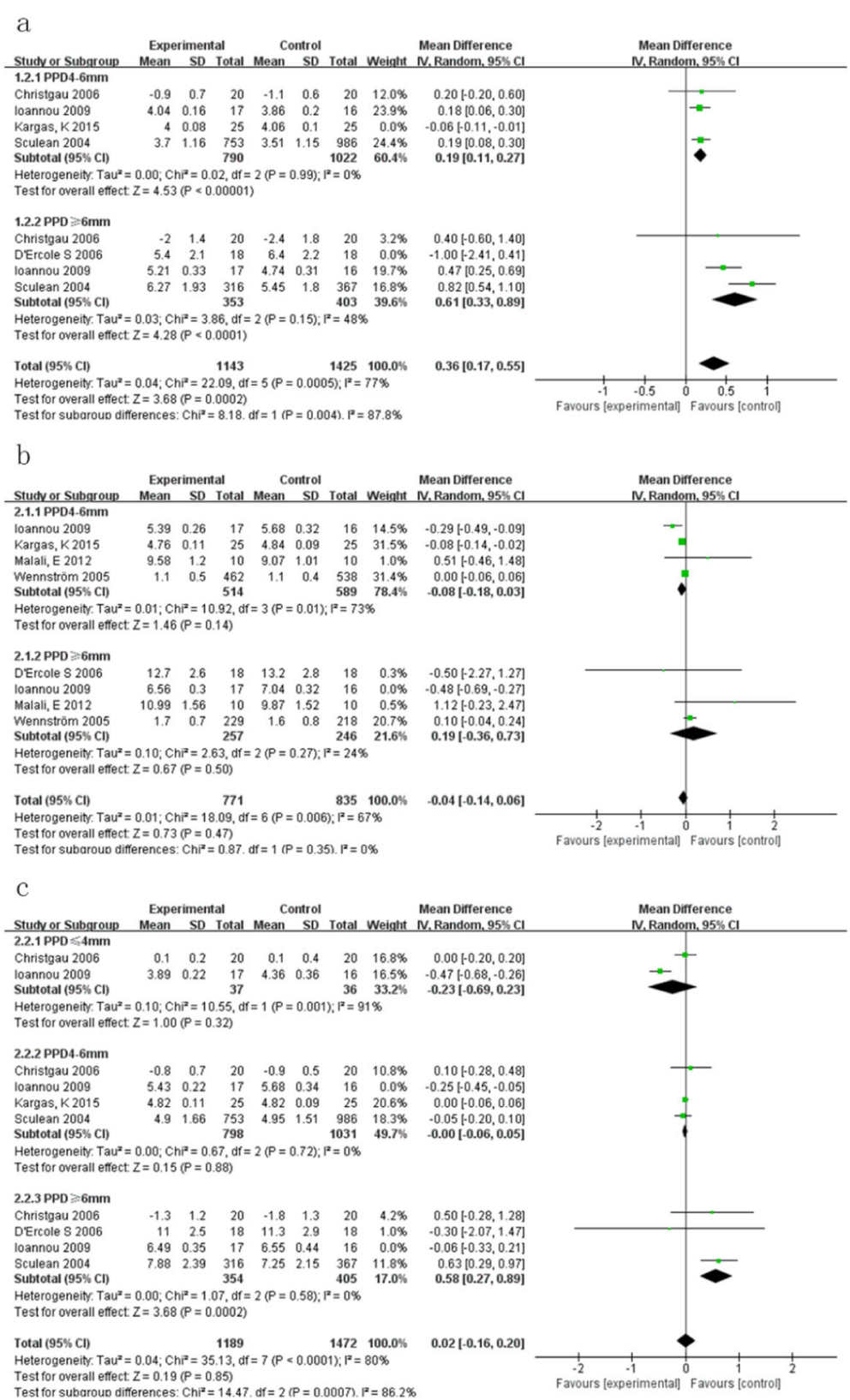

Fig. 4 a. Sensitivity analysis of PPD at 6-months in terms of the following: 1.2.1 initial PPD 4-6 mm; 1.2.2 initial PPD $\geq 6$ mm. b. Sensitivity analysis of CAL at 3-months in terms of the following: 2.1.1 initial PPD 4-6 mm; 2.1.2 initial PPD $\geq 6 \mathrm{~mm}$. c. Sensitivity analysis of CAL at 6-months in terms of the following: 2.2.1 initial PPD $\leq 4 \mathrm{~mm} ; 2.2 .2$ initial PPD 4-6 mm; 2.2 .3 initial PPD $\geq 6 \mathrm{~mm}$

months, PPD and CAL reductions were unstable, causing large heterogeneity.

At medium depth, 6-months, Kargas et al. [15] was found to have significant heterogeneity. After excluded, heterogeneity decreased to $0 \%\left(\mathrm{Tau}^{2}=0.00 ; \mathrm{Chi}^{2}=0.02, \mathrm{df}=2\right.$ $\left.(P=0.99) ; \mathrm{I}^{2}=0 \%\right)$. The results showed statistically significant differences between manual and ultrasound groups. PPD reduction after manual subgingival scaling was greater than ultrasonic subgingival scaling (MD 0.19,95\%CI [0.11, 0.27], $P<0.00001)$. Compared with the other three studies, only non-smokers were included in this study, which might be the reason for heterogeneity (Fig. 4a).

When initial PPD was deep at 6 months, D'Ercole [16] was a major origin of heterogeneity. After exclusion, heterogeneity decreased to $\left(\mathrm{Tau}^{2}=0.03 ; \mathrm{Chi}^{2}=3.86, \mathrm{df}=2\right.$ $\left.(P=0.15) ; \mathrm{I}^{2}=48 \%\right)($ Fig. 4a). 


\section{Outcome:CAL}

When initial PPD was medium, at 3-months follow-up, the heterogeneity of CAL was high $\left(\mathrm{Tau}^{2}=0.01 \mathrm{Chi}^{2}=\right.$ $\left.10.92, \mathrm{df}=3(P=0.01) ; \mathrm{I}^{2}=73 \%\right)$. According to a sensitivity analysis, four studies were highly heterogeneous with each other, making them unsuitable for meta-analysis (Fig. 4b). The heterogeneity source was also thought to be: (1) too few studies; (2) tissue healing took time and early intervening probing may damage attachment gain. When the follow-up period was only 3 months, CAL were unstable which caused great heterogeneity.

Heterogeneity was also large in the following three groups: 1) deep pocket, at 3-months follow-up; 2) medium pocket, at 6-months follow-up; 3) deep pocket, at 6-months follow-up. After excluding Ioannou 2009 [12], heterogeneity decreased from: $87,52,71$ to $24 \%, 0$, $0 \%$. This study was the only one in which $50 \%$ of the patients were smokers, while other papers were unclear about the ratio of smokers or had a small number of smokers, which might be the reason for heterogeneity. After exclusion, at deep pocket depth of a 6-months follow-up, after manual subgingival scaling, CAL reduction was more than ultrasonic subgingival scaling and were statistically different. (MD $0.58,95 \% \mathrm{CI}[0.27,0.89]$, $P=0.0002$ ) (Fig. 4b, Fig. 4c).

In the same study, heterogeneity of PPD and CAL was much greater at 3-months than at 6-months follow-up. The influence was quite apparent at medium PPD, 3months. At deep initial depths, either 3-months or 6months, heterogeneity was acceptable. The reason could be that the tissue took time to heal. In deep pocket, tissue contacted and attached to the bone better, resulting in shorter healing time and more stable condition within 3 months. At medium pocket depths, tissue did not contact bone as readily as at deeper pockets, so healing time was longer. Probing too early in healing process may damage tissue and influence attachment gain, and led to unstable results.

\section{Quality of evidence}

After evaluating the quality of data with the GRADE system, the following results were obtained: the data of PPD at 3-months and 6-months follow-up of shallow pocket, and CAL at 3-months follow-up of shallow pocket was of very low quality; the data of PPD at 3months follow-up of medium pocket, CAL at 3-months follow-up of medium and deep pocket and at 6-months follow-up of shallow pocket was of low quality; the data of PPD at 3-months follow-up of medium pocket, at 6months follow-up of medium and deep pocket and CAL at 6-months follow-up of medium and deep pocket was of moderate quality. Details were given in the Appendix 6. The data of shallow pocket mostly was of very low quality because of too small sample size and publication bias, so that we could not draw a reliable conclusion and more studies are required. The data of 3-months followup was of low or very low quality, which might due to the fact that tissue healing took time and early probing disrupted attachment gains. We thought 3-months follow-up was too short and we cannot draw reliable conclusions according to the data of it. The data of PPD and CAL at 6-months follow-up for the medium and deep pocket groups was of moderate quality. Based on the above, we thought the conclusion should be drawn according to the data of 6-months follow-up of medium and deep pocket groups.

According to the above analysis, different indicators showed statistical significance between ultrasonic and manual subgingival scaling, which indicated the different effectiveness in clinic after the treatment of ultrasonic and manual instruments.

In addition, in shallow pocket, CAL increased after both ultrasonic and manual subgingival scaling, which might be resulted from junctional epithelium attachment damage [17]. We have also found it clinically. Therefore, manual subgingival scaling is not recommended when PPD is less than $4 \mathrm{~mm}$. In clinical practice, when PPD is less than $4 \mathrm{~mm}$ and there is symptom such as bleeding on probing or subgingival dental calculus, ultrasonic subgingival working tip can be used for deep cleaning.

In terms of GR, at medium or deep PPD, there was no differences between manual and ultrasonic subgingival scaling, whatever the roots were single or multiple $[15,18]$.

BOP results of one study [17] showed, at 6-months follow-up, more BOP reduction at deep depths after manual scaling than ultrasound.

Residual calculus provided different results. Two studies $[20,21]$ indicated that, regardless of depth, there were no statistical differences in calculus clearance rates between ultrasound and manual treatment. Schwarz [19] indicated when PPD was deep, for a single-root tooth, ultrasonic dental calculus removal was more effective than manual subgingival scaling.

Above all, ultrasonic subgingival scaling is an efficient non-surgical treatment [7], yet manual subgingival scaling is also essential and cannot be replaced by ultrasonic method.

According to the newly-released 2018 periodontitis classifications, there are something about it:

1. Different economic and health care developments between developed and developing countries make different influences on periodontitis [22, 23]. Primary CAL in developing countries was three times of developed countries [23]. Only one study [13] involved a developing country (Turkey). Whether the conclusions reached in this paper apply to developing countries is unknown. 
2. Smoking is confirmed as affecting progress of periodontitis and was considered in the new classification [22]. Most of the included studies chose patients according to the 1999 classification and did not consider the impact of smoking, which may lead to heterogeneity.

\section{Summary \\ Significance to clinical practice}

(1) Combining our above analysis and quality of evidence, we believed that only 6-months follow-up results could be used to reach following conclusions:

a. When initial PPD was shallow, no conclusions were drawn due to the limited number of studies.

b. When initial PPD was medium, PPD reductions proved that manual subgingival scaling was superior. CAL and GR results showed no statistical differences. More studies are needed before any conclusion can be drawn.

c. When initial PPD was deep, manual subgingival scaling was superior in terms of PPD, CAL and BOP results, while GR results showed no statistical differences. This conclusion also needs more study because of the limited number of studies.

(2) In terms of residual dental calculus, there was no conclusion could be drawn.

\section{Significance to research}

(1) Inclusion and exclusion criteria could refer to the new classification to reduce bias;

(2) Studies should consider other indicators such as BOP, PI, and GI, bacterial changes, when comparing in different PPDs;

(3) More studies are needed in developing countries;

(4) Single and multiple root teeth should be measured separately;

(5) Further studies should enlarge sample sizes to improve credibility;

(6) Inclusion or exclusion criteria for smokers should be standardized.

(7) Studies with a follow-up period of 6 months or longer are suggested to determine reliable results.

\section{Conclusions}

Ultrasonic subgingival scaling is an efficient non-surgical treatment of periodontitis. However, when initial PPD was 4-6 $\mathrm{mm}$, PPD reduction proved manual subgingival scaling was superior, but CAL results showed no statistical differences between the two means. When initial PPD was $\geq 6 \mathrm{~mm}$, PPD and CAL reductions suggested that manual subgingival scaling was superior. Manual subgingival scaling is significant and cannot be completely replaced by ultrasonic subgingival scaling. We suggest, when initial PPD is medium or deep, using ultrasonic and manual subgingival instruments together.

\section{Supplementary information}

Supplementary information accompanies this paper at https://doi.org/10. 1186/s12903-020-01117-3.

Additional file 1 Appendix 1. Search strategy used in PubMed/ MEDLINE. Appendix 2. Data merger formulas. Appendix 3. Characteristics of studies awaiting classification. Appendix 4. Risk of bias graph. Appendix 5. Risk of bias summary. Appendix 6. GRADE quality of evidence.

\section{Abbreviations}

AL: Attachment level; BOP: Bleeding on probing; CAL: Clinical attachment loss; GR: Gingival recession; MD: Mean depth; PPD: Probing pocket depth

\section{Acknowledgements}

The authors wish to thank Stephen Laudig for proofreading the English language of this article.

\section{Authors' contributions}

$X Z, Z H$ and XSZ contributed equally to this work. XZ, ZH and XSZ designed the research with $W L$ and $J C$. And $X Z, Z H$ and $X S Z$ finished the acquisition, analysis and interpretation of the data. Then XZ, ZH and XSZ have drafted the work and revised the manuscript under the guidance of JC and WL. All authors have read and approved the manuscript.

\section{Funding}

Our study was supported by the Natural Science Foundation of Hunan Province for Young Scientists, China (Grant No: 2019JJ50784 to WL), the Young Teacher's Institutional grant from Xiangya School of Stomatology and Xiangya Stomatological Hospital, Central South University (Grant No: 2018YQ02 to WL), and the National-level College Students' Innovative Entrepreneurial Training Plan Program of China (Grant No: S201910533045), which provided economic support for our study in its previous research design data anaylsis software and data collection. The funders had no role in study design, data collection and analysis, decision to publish, or preparation of the manuscript.

Availability of data and materials

We declared that materials described in the manuscript, including all relevant raw data, will be freely available to any scientist wishing to use them for non-commercial purposes, without breaching participant confidentiality. All data generated or analyzed during this study are included in this published article (and its supplementary information files).

Ethics approval and consent to participate

Not applicable for that section.

\section{Consent for publication}

Not applicable for that section.

\section{Competing interests}

The authors declare that they have no competing interests.

\section{Author details}

${ }^{1}$ Department of Orthodontics, Xiangya School of Stomatology, Central South University, Changsha 410008, People's Republic of China. ${ }^{2}$ Hunan Key Laboratory of Oral Health Research, Hunan 3D Printing Engineering Research Center of Oral Care, Hunan Clinical Research Center of Oral Major Diseases and Oral Health, Central South University, Changsha 410008, People's Republic of China. ${ }^{3}$ National Key Laboratory of Science and Technology for National Defence on High-strength Structural Materials, Central South University, Changsha 410008, People's Republic of China. ${ }^{4}$ State Key 
Laboratory of Powder Metallurgy, Central South University, Changsha 410008, People's Republic of China. ${ }^{5}$ Department of Periodontics, Xiangya Stomatological Hospital, Xiangya School of Stomatology, Central South University, Changsha 410008, People's Republic of China.

\section{Received: 26 July 2019 Accepted: 19 April 2020}

Published online: 25 June 2020

\section{References}

1. Chapple ILC, Van der Weijden F, Doerfer C, Herrera D, Shapira L, Polak D, Madianos P, Louropoulou A, Machtei E, Donos N, et al. Primary prevention of periodontitis: managing gingivitis. J Clin Periodontol. 2015;42(Suppl 16): S71-6.

2. Kassebaum NJ, Bernabé E, Dahiya M, Bhandari B, Murray CJL, Marcenes W. Global burden of severe periodontitis in 1990-2010: a systematic review and meta-regression. J Dent Res. 2014;93(11):1045-53.

3. Chapple ILC, Bouchard P, Cagetti MG, Campus G, Carra M-C, Cocco F, Nibali $L$, Hujoel $P$, Laine ML, Lingstrom $P$, et al. Interaction of lifestyle, behaviour or systemic diseases with dental caries and periodontal diseases: consensus report of group 2 of the joint EFP/ORCA workshop on the boundaries between caries and periodontal diseases. J Clin Periodontol. 2017;44(Suppl 18):S39-51.

4. Tonetti MS, Jepsen S, Jin L, Otomo-Corgel J. Impact of the global burden of periodontal diseases on health, nutrition and wellbeing of mankind: a call for global action. J Clin Periodontol. 2017:44(5):456-62.

5. Badersten A, Nilveus R, Egelberg J. Effect of nonsurgical periodontal therapy I: moderately advanced periodontitis. J Clin Periodontol. 1981;8(1).

6. Obeid PR, D'Hoore W, Bercy P. Comparative clinical responses related to the use of various periodontal instrumentation. J Clin Periodontol. 2004;31(3): 193-9.

7. Arabaci T, Ciçek Y, Canakçi CF. Sonic and ultrasonic scalers in periodontal treatment: a review. Int J Dent Hyg. 2007;5(1):2-12.

8. Heitz-Mayfield LJ, Lang NP. Surgical and nonsurgical periodontal therapy. Learned and unlearned concepts. Periodontology. 2000;62(1):218-31.

9. Suvan JE. Effectiveness of mechanical nonsurgical pocket therapy. Periodontology. 2000;37:48-71.

10. Beuchat M, Busslinger A, Schmidlin PR, Michel B, Lehmann B, Lutz F. Clinical comparison of the effectiveness of novel sonic instruments and curettes for periodontal debridement after 2 months. J Clin Periodontol. 2001;28(12): $1145-50$.

11. Higgins JPT, Thomas J, Chandler J, Cumpston M, Li T, Page MJ, VA W. Cochrane handbook for systematic reviews of interventions, 2 nd edn. Chichester UK: John Wiley \& Sons; 2019

12. Ioannou I, Dimitriadis N, Papadimitriou K, Sakellari D, Vouros I, Konstantinidis A. Hand instrumentation versus ultrasonic debridement in the treatment of chronic periodontitis: a randomized clinical and microbiological trial. J Clin Periodontol. 2009;36(2):132-41.

13. Malali E, Kadir T, Noyan U. Er:YAG lasers versus ultrasonic and hand instruments in periodontal therapy: clinical parameters, intracrevicular micro-organism and leukocyte counts. Photomed Laser Surg. 2012;30(9): 543-50.

14. Wennström JL, Tomasi C, Bertelle A, Dellasega E. Full-mouth ultrasonic debridement versus quadrant scaling and root planing as an initial approach in the treatment of chronic periodontitis. J Clin Periodontol. 2005; 32(8):851-9.

15. Kargas K, Tsalikis L, Sakellari D, Menexes G, Konstantinidis A. Pilot study on the clinical and microbiological effect of subgingival glycine powder air polishing using a cannula-like jet. Int J Dent Hyg. 2015;13(3):161-9.

16. D'Ercole S, Piccolomini R, Capaldo G, Catamo G, Perinetti G, Guida L. Effectiveness of ultrasonic instruments in the therapy of severe periodontitis: a comparative clinical-microbiological assessment with curettes. New Microbiol. 2006;29(2):101-10.

17. Christgau M, Männer T, Beuer S, Hiller KA, Schmalz G. Periodontal healing after non-surgical therapy with a modified sonic scaler: a controlled clinical trial. J Clin Periodontol. 2006;33(10):749-58.

18. Sculean A, Schwarz F, Berakdar M, Romanos GE, Brecx M, Willershausen B, Becker J. Non-surgical periodontal treatment with a new ultrasonic device (vector-ultrasonic system) or hand instruments. J Clin Periodontol. 2004; 31(6):428-33.

19. Schwarz F, Bieling K, Venghaus S, Sculean A, Jepsen S, Becker J. Influence of fluorescence-controlled Er:YAG laser radiation, the vector system and hand instruments on periodontally diseased root surfaces in vivo. J Clin Periodontol. 2006:33(3):200-8.

20. Yukna RA, Scott JB, Aichelmann-Reidy ME, LeBlanc DM, Mayer ET. Clinical evaluation of the speed and effectiveness of subgingival calculus removal on single-rooted teeth with diamond-coated ultrasonic tips. J Periodontol. 1997;68(5):436-42

21. Gellin RG, Miller MC, Javed T, Engler WO, Mishkin DJ. The effectiveness of the titan-S sonic scaler versus curettes in the removal of subgingival calculus. A human surgical evaluation. J Periodontol. 1986;57(11):672-80.

22. Papapanou PN, Sanz M, Buduneli N, Dietrich T, Feres M, Fine DH, Flemmig TF, Garcia R, Giannobile WV, Graziani F, et al. Periodontitis: consensus report of workgroup 2 of the 2017 world workshop on the classification of periodontal and Peri-implant diseases and conditions. J Periodontol. 2018; 89(Suppl 1):S173-s182.

23. Needleman I, Garcia R, Gkranias N, Kirkwood KL, Kocher T, lorio AD, Moreno F, Petrie A. Mean annual attachment, bone level, and tooth loss: a systematic review. J Clin Periodontol. 2018;45(Suppl 20):S112s129.

24. Dibart S, Capri D, Casavecchia P, Nunn M, Skobe Z. Comparison of the effectiveness of scaling and root planing in vivo using hand vs rotary instruments. Int J Periodontics Restorative Dentistry. 2004:24(4):370-7.

25. Van Dijk LJ, Lie MA, Van den Heuvel ER, Van der Weijden GA. Adult periodontitis treated with a new device for subgingival lavage-a randomized controlled clinical trial using a split-mouth design. Int J Dent Hyg. 2018;16(4):559-68.

26. Wang Y, Li W, Shi L, Zhang F, Zheng S. Comparison of clinical parameters, microbiological effects and calprotectin counts in gingival crevicular fluid between Er: YAG laser and conventional periodontal therapies: a splitmouth, single-blinded, randomized controlled trial. Medicine. 2017;96(51): e9367.

27. Dukić W, Bago I, Aurer A, Roguljić M. Clinical effectiveness of diode laser therapy as an adjunct to non-surgical periodontal treatment: a randomized clinical study. J Periodontol. 2013:84(8):1111-7.

28. Slot DE, Timmerman MF, Versteeg PA, van der Velden $U$, van der Weijden FA. Adjunctive clinical effect of a water-cooled Nd: YAG laser in a periodontal maintenance care programme: a randomized controlled trial. J Clin Periodontol. 2012;39(12):1159-65.

29. Biagini G, Checchi L, Miccoli MC, Vasi V, Castaldini C. Root curettage and gingival repair in periodontitis. J Periodontol. 1988;59(2):124-9.

30. Oberholzer R, Rateitschak KH. Root cleaning or root smoothing. An in vivo study. J Clin Periodontol. 1996;23(4):326-30.

31. Slot DE, Kranendonk AA, Van der Reijden WA, Van Winkelhoff AJ, Rosema NAM, Schulein WH, Van der Velden U, Van der Weijden FA. Adjunctive effect of a water-cooled Nd:YAG laser in the treatment of chronic periodontitis. J Clin Periodontol. 2011;38(5):470-8.

32. Romeo U, Palaia G, Botti R, Leone $V$, Rocca JP, Polimeni A. Non-surgical periodontal therapy assisted by potassium-titanyl-phosphate laser: a pilot study. Lasers Med Sci. 2010;25(6):891-9.

33. Yukna RA, Carr RL, Evans GH. Histologic evaluation of an Nd:YAG laserassisted new attachment procedure in humans. Int J Periodontics Restorative Dentistry. 2007;27(6):577-87.

34. Feng XH, Lu RF, He L. A short-term clinical evaluation of periodontal treatment with an Er:YAG laser for patients with chronic periodontitis: a split-mouth controlled study. Beijing Da Xue Xue Bao. 2011;43(6):886-90.

35. Wu K-Y, Xu C-J, Chi Y-T, Sun X-J, Wang H-F. Detection of Dickkopf-1 and alkaline phosphatase activity in gingival crevicular fluid from chronic periodontitis with Er:YAG laser as an adjunctive treatment. Shanghai Kou Qiang Yi Xue. 2017;26(3):285-9.

36. Petelin M, Perkič K, Seme K, Gašpirc B. Effect of repeated adjunctive antimicrobial photodynamic therapy on subgingival periodontal pathogens in the treatment of chronic periodontitis. Lasers Med Sci. 2015;30(6):164756.

37. Mittal A, Nichani AS, Venugopal R, Rajani V. The effect of various ultrasonic and hand instruments on the root surfaces of human single rooted teeth: a Planimetric and Profilometric study. J Ind Soc Periodontol. 2014;18(6):710-7.

38. Kishida M, Sato S, Ito K. Comparison of the effects of various periodontal rotary instruments on surface characteristics of root surface. J Oral Sci. 2004; 46(1):1-8.

39. Khosravi M, Bahrami ZS, Atabaki MS, Shokrgozar MA, Shokri F. Comparative effectiveness of hand and ultrasonic instrumentations in root surface planing in vitro. J Clin Periodontol. 2004;31(3):160-5. 
40. Gagnot G, Mora F, Poblete MG, Vachey E, Michel JF, Cathelineau G. Comparative study of manual and ultrasonic instrumentation of cementum surfaces: influence of lateral pressure. Int J Periodontics Restorative Dentistry. 2004;24(2):137-45.

41. Schwarz F, Aoki A, Sculean A, Georg T, Scherbaum W, Becker J. In vivo effects of an Er:YAG laser, an ultrasonic system and scaling and root planing on the biocompatibility of periodontally diseased root surfaces in cultures of human PDL fibroblasts. Lasers Surg Med. 2003;33(2):140-7.

42. Croft LK, Nunn ME, Crawford LC, Holbrook TE, McGuire MK, Kerger MM, Zacek GA. Patient preference for ultrasonic or hand instruments in periodontal maintenance. Int J Periodontics Restorative Dentistry. 2003;23(6): 567-73.

43. Braun A, Krause F, Nolden R, Frentzen M. Subjective intensity of pain during the treatment of periodontal lesions with the vector-system. J Periodontal Res. 2003;38(2):135-40

44. Kocher T, Rosin M, Langenbeck N, Bernhardt O. Subgingival polishing with a teflon-coated sonic scaler insert in comparison to conventional instruments as assessed on extracted teeth (II). Subgingival roughness. J Clin Periodontol. 2001:28(8)

45. Kocher $\mathrm{T}$, Rühling $\mathrm{A}$, Momsen $\mathrm{H}$, Plagmann $\mathrm{HC}$. Effectiveness of subgingival instrumentation with power-driven instruments in the hands of experienced and inexperienced operators. A study on manikins. J Clin Periodontol. 1997;24(7):498-504.

46. Copulos TA, Low SB, Walker CB, Trebilcock YY, Hefti AF. Comparative analysis between a modified ultrasonic tip and hand instruments on clinical parameters of periodontal disease. J Periodontol. 1993;64(8):694-700.

47. Kepic TJ, O'Leary TJ, Kafrawy AH. Total calculus removal: an attainable objective? J Periodontol. 1990;61(1):16-20.

48. Garnick JJ, Dent J. A scanning electron micrographical study of root surfaces and subgingival bacteria after hand and ultrasonic instrumentation. J Periodontol. 1989;60(8):441-7.

49. Breininger DR, O'Leary TJ, Blumenshine RV. Comparative effectiveness of ultrasonic and hand scaling for the removal of subgingival plaque and calculus. J Periodontol. 1987;58(1):9-18.

50. Hunter RK, O'Leary TJ, Kafrawy AH. The effectiveness of hand versus ultrasonic instrumentation in open flap root planing. J Periodontol. 1984; 55(12):697-703.

51. Thornton S, Garnick J. Comparison of ultrasonic to hand instruments in the removal of subgingival plaque. J Periodontol. 1982;53(1):35-7.

52. Nishimine D, O'Leary TJ. Hand instrumentation versus ultrasonics in the removal of endotoxins from root surfaces. J Periodontol. 1979;50(7):345-9.

53. D'Silva IV, Nayak RP, Cherian KM, Mulky MJ. An evaluation of the root topography following periodontal instrumentation--a scanning electron microscopic study. J Periodontol. 1979;50(6):283-90.

54. Ewen SJ, Scopp IW, Witkin RT, Ortiz-Junceda M. A comparative study of ultrasonic generators and hand instruments. J Periodontol. 1976;47(2):82-6.

55. Stewart JL, Drisko RR, Herlach AD. Comparison of ultrasonic and hand instruments for the removal of calculus. J Am Dental Assoc. 1939;75(1):153-7.

56. Gutknecht N, Van Betteray C, Ozturan S, Vanweersch L, Franzen R. Laser supported reduction of specific microorganisms in the periodontal pocket with the aid of an Er,Cr:YSGG laser: a pilot study. Sci World J. 2015;2015: 450258.

57. Maritato M, Orazi L, Laurito D, Formisano G, Serra E, Lollobrigida M, Molinari A, De Biase A. Root surface alterations following manual and mechanical scaling: a comparative study. Int J Dent Hyg. 2018;16(4):553-8.

58. Foroutan T, Amid R, Karimi MR. Comparison of manual tools, ultrasonic and erbium-doped yttrium aluminum garnet (Er:YAG) laser on the debridement effect of the surface of the root of teeth suffering from periodontitis. J Lasers Med Sci. 2013;4(4):199-205.

59. Geng SF, Xu L, Ying P, Cao CF. Clinical evaluation of manual and ultrasonic subgingival scaling using image analysis. Shanghai Kou Qiang Xue. 1992; 1(2):73-6.

60. Kahl M, Haase $E$, Kocher T, Rühling A. Clinical effects after subgingival polishing with a non-aggressive ultrasonic device in initial therapy. J Clin Periodontol. 2007;34(4):318-24.

61. Kocher T, Plagmann HC. Root debridement of molars with furcation involvement using diamond-coated sonic scaler inserts during flap surgery -- a pilot study. J Clin Periodontol. 1999;26(8):525-30.

62. Badersten A, Nilveus R, Egelberg J. Effect of nonsurgical periodontal therapy II: severely advanced periodontitis. J Clin Periodontol. 1984;11(1).
63. Oosterwaal PJ, Matee MI, Mikx FH, van't Hof MA, Renggli HH. The effect of subgingival debridement with hand and ultrasonic instruments on the subgingival microflora. J Clin Periodontol. 1987;14(9):528-33.

\section{Publisher's Note}

Springer Nature remains neutral with regard to jurisdictional claims in published maps and institutional affiliations.
Ready to submit your research? Choose BMC and benefit from:

- fast, convenient online submission

- thorough peer review by experienced researchers in your field

- rapid publication on acceptance

- support for research data, including large and complex data types

- gold Open Access which fosters wider collaboration and increased citations

- maximum visibility for your research: over $100 \mathrm{M}$ website views per year

At BMC, research is always in progress.

Learn more biomedcentral.com/submissions 